LOCKHEED MARTIN/7

\section{ENVIRONMENTAL} RESTORATION PROGRAM

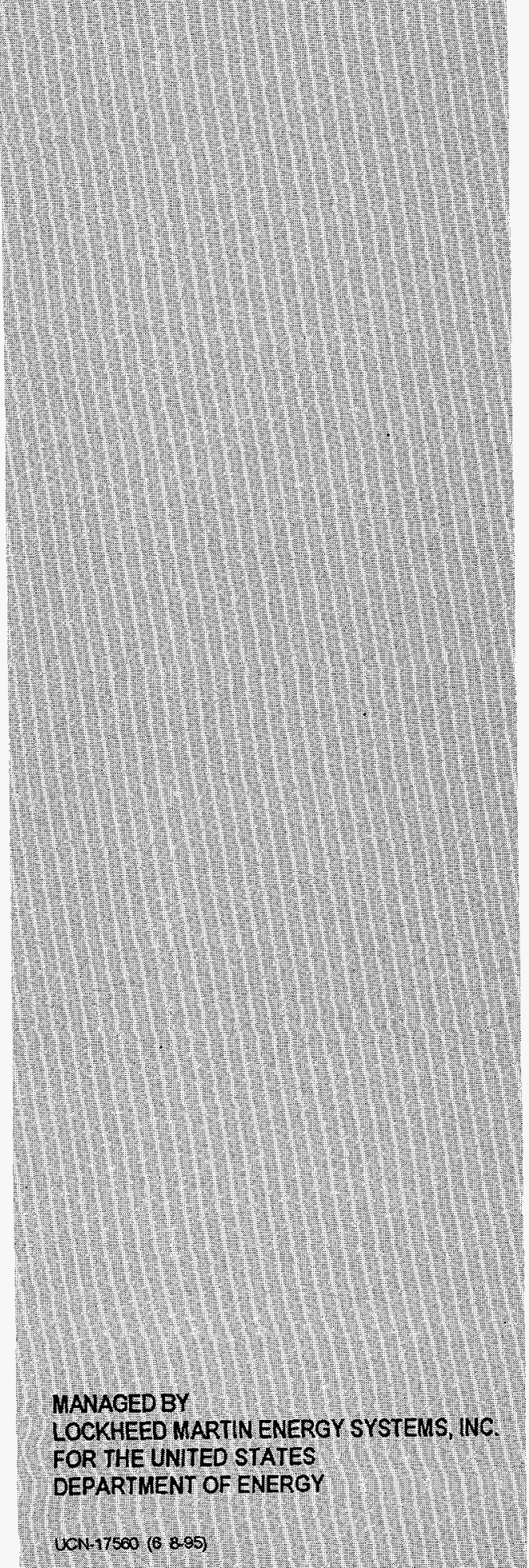

Y/ER/MS-11

\title{
Best Management Practices Plan for Installation of and Monitoring at Temporary Weirs at NT-4, Oak Ridge Y-12 Plant, Oak Ridge, Tennessee
}

\section{RECEIVED}

JUL 024997

O.STI

This document has been approved by the Y-12 Plant Technical Information Office for release to the public. Date: $6 / 3 / 97$ 


\title{
Best Management Practices Plan for Installation of and Monitoring at Temporary Weirs at NT-4, Oak Ridge Y-12 Plant, Oak Ridge, Tennessee
}

Date Issued-June 1997

\author{
Prepared by \\ Water Compliance Program \\ Environmental Management Department \\ Health, Safety, Environment, \\ and Accountability Organization \\ Prepared for the \\ U.S. Department of Energy \\ Office of Environmental Management \\ under budget and reporting code EW 20 \\ Environmental Management Activities at the \\ OAK RIDGE Y-12 PLANT \\ Oak Ridge, Tennessee 37831 \\ managed by \\ LOCKHEED MARTIN ENERGY SYSTEMS, INC. \\ for the \\ U.S. DEPARTMENT OF ENERGY \\ under contract DE-AC05-84OR21400
}




\section{DISCLAMMER}

Portions of this document may be illegible in electronic image products. Images are produced from the best available original document. 


\section{APPROVALS}

BEST MANAGEMENT PRACTICES PLAN FOR INSTALLATION OF AND MONITORING AT TEMPORARY WEIRS AT NT-4

MAY 1997

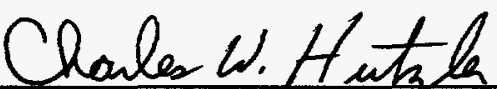

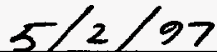

C. W. Hutzler, Environment Managemert Waste Planning

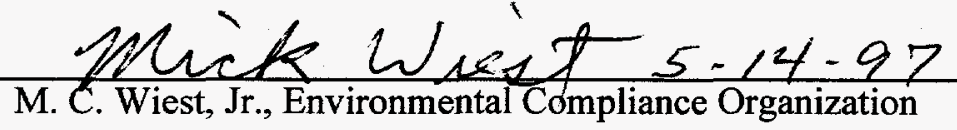




\section{BEST MANAGEMENT PRACTICES PLAN \\ FOR INSTALLATION OF AND MONITORING \\ AT TEMPORARY WEIRS AT NT-4}

\section{PURPOSE}

This Best Management Practices (BMP) Plan has been developed in order to maintain compliance with applicable regulatory requirements by documenting the practices that are required during the installation and maintenance of temporary weirs at the NT-4 tributary, subsequent collection of water discharge data, and removal of the weirs. The practices included in this BMP comply with the Clean Water Act and the intent of Sect. 70-8-104(b) of the Tennessee Code Annotated: Tennessee Wildlife Resources Commission Proclamation 94-16 to prevent the destruction of the habitat of state-listed wildlife species that are designated as "in need of management."

\section{INTRODUCTION}

The purpose of the installation of temporary weirs at NT-4 is to collect empirical surface water discharge data for the tributary during baseflow conditions and following rainfall events, during the spring and summer of 1997 in support of the Department of Energy's (DOE's) Oak Ridge Reservation Waste Management Alternatives Evaluation project. The duration of surfacewater monitoring activities is not planned to exceed 6 months.

A minimum of four temporary weirs will be installed along the length of NT-4 in the locations indicated on Attachment A. The design specifications and locations for the weirs will be provided by the DOE prime contractor for the Oak Ridge Reservation Waste Management Alternatives Evaluation project. The weirs will be fabricated by the Y-12 labor forces of Lockheed Martin Energy Systems (LMES). The Environmental Compliance Organization (ECO) of LMES will perform data collection in addition to weir installation, inspection, maintenance, and removal. Flow meters that collect data at five minute intervals will be installed on each weir and visual measurements using staff gauges mounted on each weir will also be performed.

\section{Weir Installation}

A sledge hammer will be used to install the weirs by driving each weir into the stream bank and bottom perpendicular to stream flow. Field measurements will be taken to ensure that each weir is plumb. Two rebar bracings will be driven to an approximate depth of $2 \mathrm{ft}$ into the stream bed on the downstream side of the weir. Weir installation sites will be selected to ensure the designated storm-water control points specified in the Y-12 National Pollutant Discharge Elimination System (NPDES) Permit(s) are avoided by $50-100 \mathrm{ft}$. 


\section{Weir Maintenance and Silt Removal}

Inspection of the weirs will be conducted by ECO each time measurements are collected (i.e., every other week) and after storm events. A level will be used ensure that the weirs are plumb before discharge measurements are made. If necessary, the weir will be re-leveled prior to collecting measurements.

In addition as a part of pre-measurement inspections, ECO will check for accumulation of silt on the upstream side of each weir. Any significant accumulation of silt will be removed after measurements are made, unless the silting interferes with data collection. Silt should be removed by shoveling it into a portable container that can be emptied some distance (e.g., $50 \mathrm{ft}$ ) from the stream so that silt can not reenter the stream. Under no circumstance should the silt be poured directly into the stream. Weir inspections and maintenance activities will be recorded in field logbooks.

In the event that a flume must be substituted for a weir, the LMES Project Manager will this coordinate action and approvals required by LMES, ECO, and the DOE prime contractor. This BMP Plan will be revised as necessary if any subsequent or additional requirements or instructions are required.

\section{Data Collection}

Discharge measurements will be collected every two weeks, and recorded to the nearest $0.01 \mathrm{ft}$, using the staff gauge mounted on each weir and by download from the flow meters. Data reports will consist of computer files photocopies of field book entries and include measurement, inspection, and maintenance activities as specified by the DOE prime contractor.

\section{Weir Removal}

At the end of the project, each of the weirs will be removed and retained by ECO. Any silt accumulation shall be removed prior to disturbing the weirs and the silt shall be relocated as described above.

\section{SPECIAL CONSIDERATIONS}

The project recognizes that collection of flow data during the months of May and June requires special consideration from an environmental perspective as this season typically falls within the spawning period for the Tennessee dace, which is designated as an aquatic species of concern in need of management in the state of Tennessee. However, the collection of this data at this location during the wet season is imperative; in addition, the schedule and associated milestones associated with DOE project requiring the collection of surface water discharge data at NT-4 could be impacted if this data cannot be collected until the next seasonal opportunity. Any potential impact on the Tennessee dace will be minimized by complying with the requirements identified in this BMP during all field activities. 


\section{BEST MANAGEMENT PRACTICES}

1. Designated storm-water control points specified in the $Y-12$ National Pollutant Discharge Elimination System (NPDES) Permit(s) will be avoided by $50-100 \mathrm{ft}$.

2. Every effort shall be made to minimize the potential for siltation during weir installation and all other field activities. In the event that loose soil or sediment is generated or bare areas are created, the areas will be seeded and strawed.

3. Weir inspections shall be conducted every other week and after storm events as a routine part of data collection activities. Inspections shall include observation for accumulation of silt on the upstream side of the weirs.

4. Accumulation of silt should be removed after measurements are made, unless the silting interferes with data collection by shoveling the silt into a portable container that can be emptied some distance (e.g., $50 \mathrm{ft}$ ) from the stream. Under no circumstance should the silt be poured directly into the stream.

5. Information to be recorded in the field logbook shall include date, time, monitoring event (i.e., weekly or post-storm), location, measurement data, field conditions and weir inspection observations, weir maintenance activities (e.g., silt removal), and other pertinent observations.

6. In the event that a spill or leak is observed or any adverse condition to surface waters or aquatic life occurs, the Y-12 Plant Shift Superintendent will be immediately contacted at 574-7172. 
ATTACHMENT A:

MAP OF PROPOSED WEIR LOCATIONS 


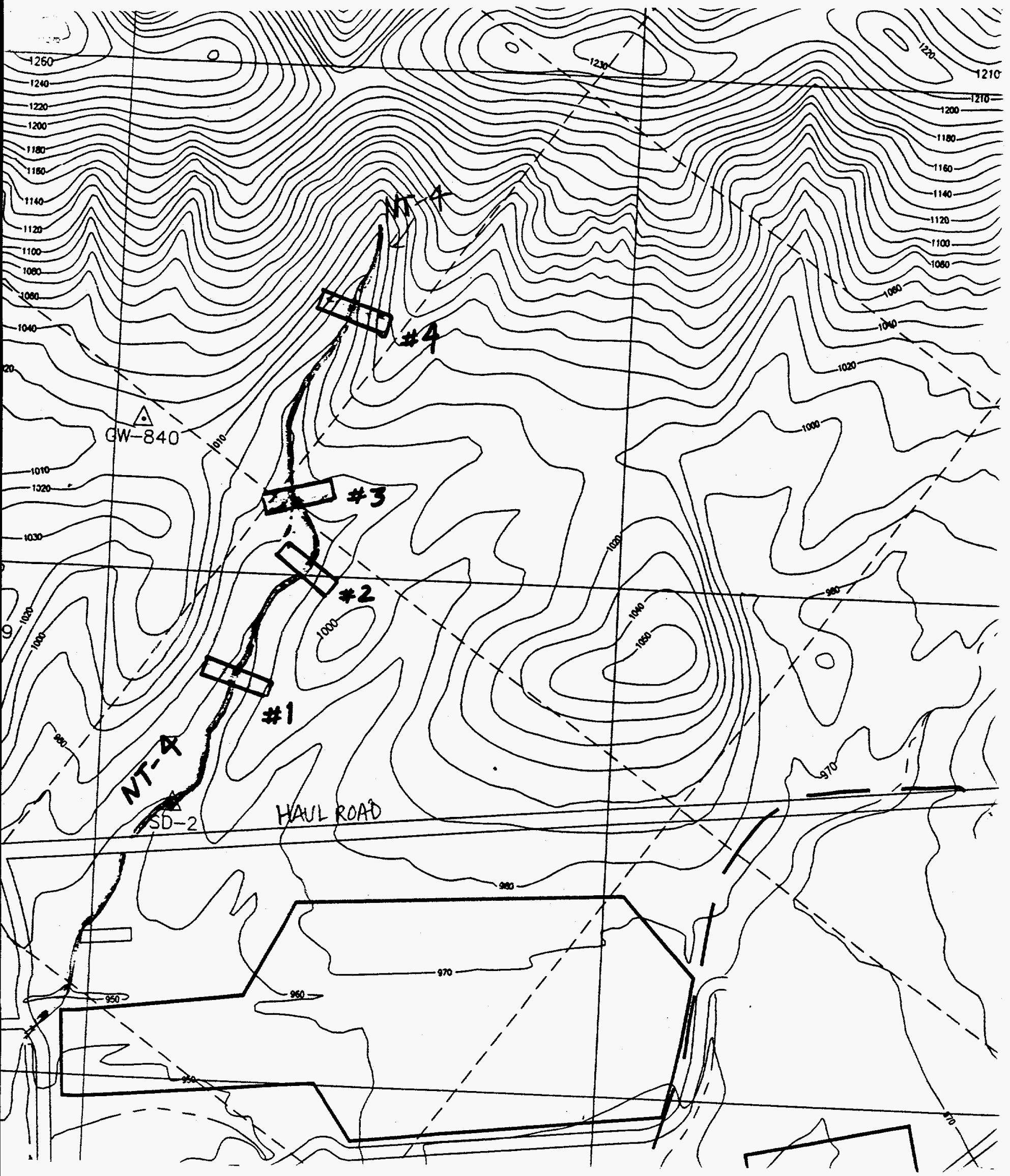

Locations of temporary weirs at NT-4. 


\section{DISTRIBUTION}

1. L. V. Asplund

2. W. J. Cahill

3. S. D. Easterling

4. C. W. Hutzler

5. L. W. Manis

6. H. C. Newsom

7. P. T. Owen

8. L. B. Raulston

9. L. O. Vaughn

10. M. C. Wiest, Jr.

11. File-EMEF DMC-RC

12. G. D. Weiss, Jacobs Engineering Group, 125 Broadway Avenue, Oak Ridge, TN 37830 